\title{
THE BMT ROLE IN DISSOLVING MONEYLENDERS LINKS AND THEORY
}

\author{
Imron Soleh \\ Muhammad Adi Cahyadi \\ Achmad Boys Awaluddin Rifai \\ Mater Candidate of Islamic Economic, Trisakti University
}

\begin{abstract}
Baitul Maal wa Tamwil (BMT) is the microfinance institution that has a significant role to help breaking moneylenders practice which have been trapped the community. However, practically BMT still has not been able to break riba due to need for urgent funds; fast process, easy requirements, and short-term for payment; community have many difficulties to access finance institution; the lack of BMT socialization; the lack of community awareness to leave riba.
\end{abstract}

Keywords: Baitul Maal wa Tamwil (BMT), Moneylenders.

\section{Introduction}

BMT is Islamic microfinance institution which has grown from, by and for community. BMT development which is grown rapidly has extended to almost all areas in Indonesia. Since developed firstly by Salman Mosque activists in 1984, total BMT registered in Absindo are 5,000 unit.

The presence of BMT as a micro financial institution that do their activities based on the principle of syariah provide an alternative financial services for the community to be able to fulfill their needs with more syar'i and amanah. Furthermore, the presence of BMT also provides small entrepreneurs to obtain capital and improve the living standards of small traders.

The community and smaller traders condition that was often considered to be not capable by the bank or financial institution has created many problems in society. Then they make moneylenders as the path to fulfill their capital and their daily needs. In economics, the presence of moneylenders was never discussed. Similarly to the criminal law and civil law, there is no law or regulation specifically talking about moneylenders practices.

Government effort to restrictive or eradicate moneylenders by establishing financial institution such as cooperatives is not clearlyprohibiting and crackingdown on the moneylenders, means it also seems unable to stop or deprive them. In practice, cooperative still use interest loan, although the interest rate offered lower than moneylenders given. 
Islam forbids riba clearly. This ban is stated in Al-Baqarah 278-279:

"You who have believed, fear Allah and give up what remains [due to you] of interest, if you should be believers. And if you do not, then be informed of a war [against you] from Allah and His Messenger. But if you repent, you may have your principal - [thus] you do no wrong, nor are you wronged."

The riba's ban is also clearly in Hadis which narrated by Bukhari no 2145, Kitab AlWakalah:

Narrated by Abu Said al-Khudri that in a while Bilal broughtbarni (dates with premium quality) foreRasulullah and he asked him, "From where do you get it?" Bilal answered, "I have dates with low quality and exchange two sha' for one sha' barni dates to be eaten by Rasulullah saw." Rasulullah kept saying, "Cautiously! Cautiously! This is riba, this is riba. Don't do like this! If you buy (high quality dates), sell the low quality dates to get the money and then use the money to buy the high quality dates."

Based on ayat and hadis mentioned above, that's exactly clear Islam strongly opposed to practice conducted by the moneylenders. In conclusion, BMT should come out as a solution in giving capital loans without use the interest.

\section{The Scope of BMT}

\section{a. Definition of BMT}

Legally, BMT is a microfinance syariah that are legal entities cooperatives. This reference is PP No.9 Tahun 1995 in The Implementation of The Savings and Loans Activities by Cooperatives, allowing cooperatives to apply the yield system to the profit sharing principles as applied in BMT.

According to Aziz (2004), BMT or Balai Usaha Mandiri Terpadu is microfinance institution that is operated by the profit sharing principles encouraging micro enterprises in order to raise the dignity and defend the poor. BMT is micro finance syariah which was built by initiatives and initial capital of local figure as the Salaam economics (justice, peace and welfare). Conceptually, BMT has two functions:

1. Baitul Tamwil (Bait means house and at Tamwil means the development of wealth)engage the development of productive enterprises and investment in improving the economic quality for micro and small entrepreneur, particularly in encouraging savings activities and support financing economic activity.

2. Baitul Maal (Bait means home and Maal means wealth) receive funds of zakat, infaq, and shadaqah and improve the distribution in accordance with the regulation and the amanah. 


\section{b. The Role of BMT, the Main Characteristics of BMT, and Organization Structure of BMT.}

1. The Role of BMT

In general the role BMT is doing guidance and funding based on the system of sharia. This role explains the importance of the Islamic principal on the economic life of the community. Hence, the role of BMT is:

a. Keep people from practices non-syariah economic. Active socializing to the community about the Islamic economic system and the benefit.

b. Empowering and financing small enterprises. BMT should be active to operate its function as syariah microfinance institution, by giving assistance, guidance, counseling, and supervision over the efforts of its members and the community.

c. Minimize community dependency from moneylenders. Community dependency from moneylenders mainly caused the community only lean against moneylenders to fulfill their urgent need for funds with quick and easy requirement.

d. Keep community economic justice with distribution field.BMT isrequired to be wise to give priority to provide funding for customers.

It means that BMT plays a very important role to empower communities economic and protect them from dependence of moneylenders. BMT is capable of being alternative sources of funding for the community and small entrepreneurs to fulfill the fund needs and develop their business.

2. The Main Characteristics of BMT

The main characteristics of BMT are:

a. Business oriented, profit sharing, increase the utilization of economic for its member and environment.

b. Not social institutions, but can be utilized to maximize usage of zakat, infaq and shadaqoh for the welfare of people.

c. Grown based on the role of the community around.

d. Belonging together by community within the area, not belonging by someone or community from the outside of the society.

3. Organization Structure of BMT

To ease duties of BMT, then required structure described the work flow to be done by members who is in BMT.Following the organization structure of BMT: 


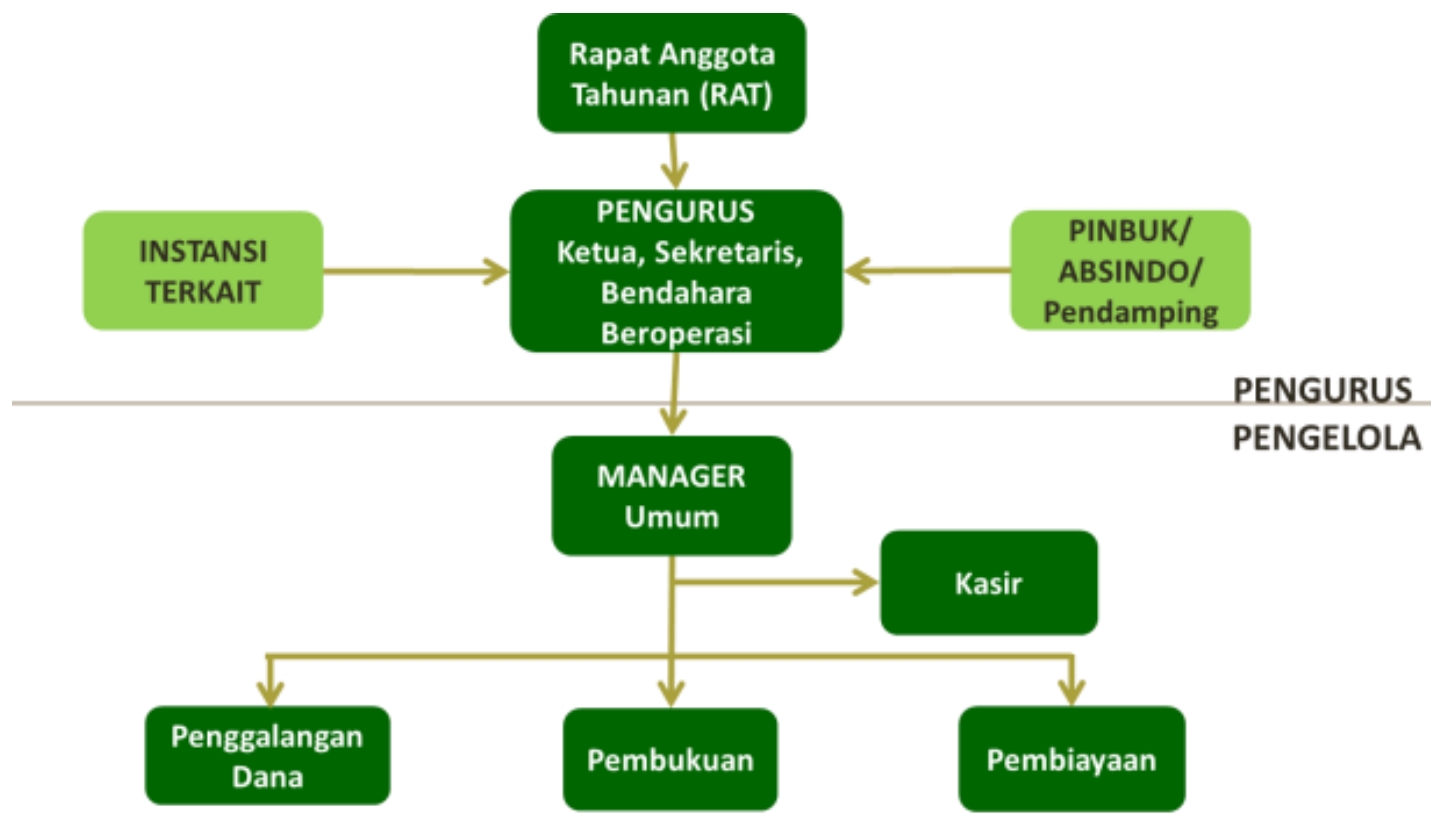

\section{Moneylenders in Islamic View}

Transactions between the community and moneylenders are supply and demand interaction where moneylenders has some money required by the community. The society necessity which is urgent on some fund in a fast manner make them come to moneylenders. They assume only moneylenders can help them in time. They are not concerned with high interest charged as long as their needs fulfilled. Financial institution is only capable giving an interesting offer with many procedures and requirements which it is difficult for the community. In business term, between moneylenders who disburse money to customers and financial institutions that disburses money to customers have the same position, making profit. The difference lies in legality and agreement $(a k a d)$. Moneylenders lend the funds to seek benefits getting personal income/profit and have no business legality. Meanwhile, financial institutions distribute funds to seek benefit not for individual business, but for community and institutions and have strong business legality.

If analysis the definition of riba is ziyadah which means additional of principal, then rentier practices is riba. According to ulamaopinions, riba is additional worn in loan (alqard) that reckoned from principal without considering outcome from the principal that is based on a certain period counted exactly in the based on the percentage of loans.

\section{Forms Transactions Loan Moneylenders}

Practice of moneylenders sometimes done by individuals, families, or particular groups. The forms of transactions normally performed by moneylenders to the community include:

a. Roving Bank / Daily Bank / Loan Package 
Roving Bank the many be an option for someone who has an urgent need for the process is quick, easy procedure, and does not require collateral. However, many people do not take into account the interest charged by moneylenders.

Debt Principal= principal: 100,000

10\% discount: 10.000

Money received: Rp.90.000

Daily installments: Rp.5.000 x $25=\mathrm{Rp} .125 .000$

Rate:(125000-90000):90,000=38.9\%Rp.125.000

Rate:(125000-90000): 90,000 $=38.9 \%$

b. Weekly Rates / Monthly Rates

Other forms of transactions moneylenders often happens in the community is a weekly or monthly interest rate. When the borrowers receive a loan, it will cut administrative costs by $10 \%$ and the beginning of the installments of $10 \%$. For example, one million loans with initial administration 100,000 and 100,000/month installments.

The debt will not be paid off if the principal amount of one million is not paid at once. If not paid within one month, then the installment the following month became Rp.110.000, so that when combined with the principal increases, it will become Rp.1.100.000. The following illustration:

\begin{tabular}{|lc|}
\hline The amount of arrears installments & Debt principal \\
InterestRate $10 \%$ & \\
0 Arrears & Rp. 1.000 .000 \\
Rp. 100.000 & \\
1 Arrears & Rp. 1.100 .000 \\
Rp.110.000 & \\
2 Arrears & Rp. 1.210 .000 \\
Rp. 121.000 & \\
3 Arrears & Rp. 1.331 .000 \\
Rp. 133.100 & \\
4 Arrears & Rp. 1.464 .100 \\
Rp. 146.410 & \\
\hline
\end{tabular}

c. Pawn leases

Pawn leases generally use physical collateral such as a motorcycle that has not paid the installment or a house that has not had a Sale and Purchase Agreements (AJB) or Certificate of Ownership (SHM). The moneylenders give some money to the owner of the motorcycle, for example, two million, then the owner of the motorcycle may continue to use his motorcycle to pay rent amounting to Rp.400.000 per month. 
During the motorcycle owners do not pay the debt, then he should continue paid the lease.

\section{Reasons for Choosing The Moneylenders}

There are still many people who use the services of moneylenders caused by factors such as the following:

a. Urgent cash needs.

The main cause people to borrow money from a loan moneylenders is a factor urgent cash needs, whether it is to meet the everyday needs as well as venture capital.

b. Loan process is fast, easy, and the repayment period is relatively short.

Another reason people borrow money from sharks because the loan process quickly and without any requirements. Prospective borrowers simply come from moneylenders and expressed his intention to borrow some money, then the borrower will soon get a loan in cash at that time or wait for some time if the loan amount is large enough. Repayment of the loan can also be performed daily, weekly, monthly or according to the agreement made at the time of borrowing. When paying for the loan installment, the borrower does not need to come to pay the debt, because usually moneylenders would come around to collect the loan money on a regular basis in accordance with the agreed time at the beginning.

c. Difficulty accessing financial institutions.

Difficulty accessing financial institutions, including the BMT, to be one of the fundamental reasons why people prefer to use the services of moneylenders. This is due to the process and requirements for obtaining financing from BMT rated cumbersome, takes a long time, and the need for collateral to borrow a particular amount. Meanwhile, society usually needs money quickly. On the other hand, the reluctance of people to go to a financial institution such as BMT. People are much more pleased if they visited, so no need to leave the activity they are doing.

d. Lack of socialization of BMT.

Lack of socialization on BMT make society still uses the services of moneylenders because it did not know the existence of BMT. They never applied for a loan to BMT for not knowing where, how, and the requirement to borrow money to BMT. Due to lack of socialization that the community does not know that the borrowed money in BMT less costly than to moneylenders.

e. The low awareness in the religious teachings of the prohibition of RIBA.

The low education and understanding of religion makes people still dependence on moneylenders. At the time of their compelling need quick funds, they visited the even though they know that the installment in BMT cheaper than moneylenders. On the other hand, moneylenders consider their business is not RIBA, but to help people who need money. The interest they charge to borrowers considered a natural thing because moneylenders operating costs need to come to customers one by one. In addition, the rates are also used to pay the mortgage and the bank interest for the loan to get capital from bank loans. 


\section{BMT Role in Combating Moneylenders}

As discussed earlier that the practice of moneylenders existed long before BMT stands. BMT role in the fight against money-lenders more focused on the financing by the BMT, the socialization of the danger and prohibition of usury and economic sharia carried out by BMT to people in order to break the chain moneylenders.

a. Financing by BMT.

One BMT attempts to break the chain of moneylenders is to provide financing to the public. BMT channel financing to customers with emphasis on the precautionary principle. In general BMT provide loans to establish the terms and procedures such as identity cards, family cards, warranties movable or immovable goods for large loans, and business ownership that has been running for at least one year for those who apply for the financing as working capital. This mechanism is done because the money is channeled is owned by client. So prudence is required because it is a mandate. Just like banks, BMT as a financial institution, in extending financing to the public need to be aware of $5 \mathrm{C}$ principles relating to the overall condition of the funding recipients, namely Character, Capacity, Capital, Collateral and Conditions of economy .

b. Socializing the BMT and the importance of establishing sharia economy.

Until now BMT not yet play a significant role in breaking the chain of moneylenders. This is because not maximal efforts of BMT in the dissemination to the public. Meanwhile, the loan moneylenders tend to be more proactive in offering their services to the public. System "proactive" conducted by moneylenders, cause people prefer to use their services because it is considered more practical and quick process. The moneylenders know the exact needs of the community for funds swift and practicality to get it. Therefore, BMT required to be more proactive in the dissemination to the public about the importance of the Islamic economic system and a ban on RIBA. BMT also should facilitate the process and the requirements of financing to customers in accordance with the feasibility assessment. And no less important, BMT must do "proactive" if you do not want to compete with the moneylenders.

c. BMT is a microfinance institution that breaks the chain of moneylenders.

Generally, people borrow money from moneylenders to meet urgent needs or as additional capital. If they apply for a loan to the bank, they are often considered to be not yet bankable. Meanwhile, if they go to pawn shops, they do not have a number of items that could be pawned for some time. In addition, there are concerns if they are unable to redeem the pawned goods back. As a shortcut, they borrow from moneylenders because it is easier and more practical even though they are burdened with higher interest charges. The assumption that moneylenders are easy and practical is what makes society into dependence on moneylenders.

Based on this, BMT attempt to break the chain of moneylenders has not been maximized. BMT should offer financing mechanism with the terms and 
procedures simpler than by submitting to the bank financing. BMT is required to know their customers more personally and knows the needs of its customers, so that BMT can provide appropriate financing schemes for its customers. In addition, BMT should provide insight to clients that the interest charged by moneylenders is unclean and Islam forbids practices relating to RIBA.

\section{Conclusion}

Although BMT has long existed among the people, but people today still use the services of moneylenders to overcome their financial problems. This is due to several things:

a. The need quick funds that is urgent.

b. Lending process is fast, easy, and the repayment period is relatively short.

c. Communities have difficulty in accessing financial institutions, including the BMT.

d. Lack of socialization on BMT.

e. The low awareness in the religious teachings of the prohibition of RIBA.

On the other hand, BMT is still not showing a significant role in breaking the chain of moneylenders. This is because BMT has not been proactive in meeting the financial needs of the community. BMT expected to be more proactive in meeting the financial needs of the community, so that the dependence on moneylenders can be reduced. Meanwhile, religious leaders expected more often give explanations and awareness to the community about the prohibition of RIBA.

\section{Referensi}

Al Qur'anul Karim

Arifin, Z. (2002). Fundamentals of Bank Management Shariah. Alvabet: Jakarta.

Aziz, M., A. (2004). Guidelines for the Establishment of BMT. PINBUK Press: Jakarta

Aziz, M., R. (2015). Islamic Economics Methodology. Journal of Research Islamic Economics Culture (RIEC) Vol. 1, No 1.

Aziz, M., A. (2016). Islam dan Pengetahuan. EsaAlam: Jakarta

Aziz, M., R. (2015). Hahslm Islamic Economics Methodology. Proceeding ICOSEC : Developing Countries Readiness Toward Global. UniversitasNegeri Solo.

Aziz, M.,R. (2012). New Paradigm on Islamic Kafah in Islamic Economics. JurnalSignifikan, Vol 1 No 2.

Aziz, M., R. (2010). New Paradigm on SinlammimKaffah in Islamic Economics. JurnalSignifikan, Vol 9 No 2.

Aziz, M., R. (2015). Teori H dalam Islam sebagai WahyudanTurats.Jurnal UIN SyarifHidayatullah. Cokrohadikusumo, Widiyanto bin Mislan, Abdul Ghafar Ismail, and Kartiko A. Wibowo. 2016. BMT: Practice and Case. PT RajaGrafindoPersada: Jakarta.

Huda, N., et al.(2012). Public Finance Islami: Theoretical Approaches and History. Prenadamedia Group: Jakarta.

http://edubuku.com/2016/03/22/larangan-riba-dalam-hadits/ accessed on July 26, 2016. 
http://www.republika.co.id/berita/ekonomi/syariah-ekonomi/15/03/22/nlmhlb-aset-bmtindonesia-capai-rp-47-triliun accessed on July 26, 2016.

http://bmtitqan.org/artikel/detail/12/siasat-rentenir.html accessed on August 2, 2016.

Soemitra, A. (2009). Banks and Islamic Financial Institutions. Prenadamedia Group: Jakarta. 